\title{
A comparative study on the biological activity of essential oil and total hydro-alcoholic extract of Satureja hortensis $\mathbf{L}$.
}

\author{
RAMONA A. POPOVICI $^{1 *}$, DELIA VADUVA ${ }^{2 *}$, IULIA PINZARU ${ }^{3}$, CRISTINA A. DEHELEAN $^{1}$, \\ CLAUDIA G. FARCAS ${ }^{3}$, DORINA CORICOVAC ${ }^{3}$, CORINA DANCIU ${ }^{3}$, IULIANA POPESCU ${ }^{4}$, \\ ERSILIA ALEXA ${ }^{5}$, VOICHITA LAZUREANU ${ }^{2}$ and HORIA T. STANCA ${ }^{6}$
}

\author{
${ }^{1}$ Faculty of Dentistry, ${ }^{2}$ Faculty of Medicine, and ${ }^{3}$ Faculty of Pharmacy, 'Victor Babes' University of Medicine and \\ Pharmacy, 300041 Timisoara; ${ }^{4}$ Faculty of Agriculture and ${ }^{5}$ Faculty of Food Processing Techology, Banat's University of \\ Agricultural Sciences and Veterinary Medicine 'King Michael I of Romania', 300645 Timisoara; \\ ${ }^{6}$ Faculty of Medicine, 'Carol Davila' University of Medicine and Pharmacy, 050474 Bucharest, Romania
}

Received August 19, 2018; Accepted February 22, 2019

DOI: 10.3892/etm.2019.7635

\begin{abstract}
Satureja hortensis L. presents an increased interest due to its chemical composition, abundant in monoterpenes, aglyconic and glycosylates flavonoids, and phenolic acids, leading to important biological activity. The present study compared the biological activity of volatile oil (VO) and total hydro-alcoholic extract (TE) of Satureja hortensis L. in terms of: i) antioxidant activity; ii) antimicrobial activity; and iii) viability, migration and proliferation on two healthy cell lines (keratinocytes-HaCaT and fibroblasts-1BR3) and two melanoma cell lines (human-A375 and murine-B164A5). Antioxidant activity of $\mathrm{VO}$ and TE showed maximal values around $72 \%$. Antimicrobial screening highlighted the inhibitory capacity of VO against all seven tested bacteria strains, with the most pronounced effect against $S$. aureus and C. albicans, while TE exerted only a slight activity against three bacteria strains. VO showed greater efficacy than TE on both tumor cell lines (A375 and B164A5), the activity of the compounds was higher when low concentrations were used $(5,10$ and $25 \mu \mathrm{M})$ while at high concentrations (50 and $100 \mu \mathrm{M})$ the percentages of viability were increased.
\end{abstract}

\section{Introduction}

Satureja hortensis L. is a plant known and used as remedy for more than 20 centuries. The name was assigned by the

Correspondence to: Dr Iulia Pinzaru, Faculty of Pharmacy, 'Victor Babes' University of Medicine and Pharmacy, 2nd Eftimie Murgu Square, 300041 Timisoara, Romania

E-mail: iuliapinzaru@umft.ro

${ }^{*}$ Contributed equally

Key words: summer savory, essential oil vs. total extract, chemical composition, antimicrobial activity, melanoma
Roman writer Pliny, being derived from the word 'satyr' (the Latin name satureia) which describes a creature from ancient mythology (half man, half goat) and the legend says that savories belonged to him (1-3). This perennial plant belongs to an important family of aromatic and medicinal herbs, Lamiaceae that includes more than 200 genera widespread in Europe (the southern and eastern regions), Asia (the western region), South America and some Spanish islands $(3,4)$. Satureja hortensis L., known as summer savory, is native of Europe, especially from the Balkan regions and its leaves and stems are currently utilized as tea, spice or flavoring agent (2).

The increased interest towards this plant is due to its chemical composition which affords important biological activity. The main classes of compounds identified, are: volatile compounds (carvacrol, thymol, $o$-cymene, $(+)$-4-carene, cis-terpinene, citronellol, geraniol, limonene, linalool, myrcene, $p$-cymene, $\alpha$-pinene and $\gamma$-terpinene), phenolic acids (rosmarinic acid, caffeic acid and gallic acid), flavonoids and associated compounds (apigenin, quercetin, naringenin, and their glycosides) and other compounds (e.g., enzymes) $(3,4)$. The main structures are presented in Fig. 1.

Satureja hortensis L. was used in folk medicine to treat various disorders, such as cramps, muscle pains, stomach, intestinal, and infectious diseases $(3,5)$. The modern techniques applied to study the effects of biologically active substances from its composition revealed a plethora of beneficial activities, such as antimicrobial, antioxidant, cytotoxic, insecticidal, fumigant toxicity, insect repellant, antinociceptive/analgesic, antileishmanial, anti-inflammatory, antidiarrheal, antispasmodic, matrix metalloproteinase inhibitory activity, inhibition on blood platelet adhesion, aggregation and secretion, effect on immune system and on rhinosinusitis (3). Taking into account the great interest for the treatment and the prophylaxis of different pathologies, the plant material should be meticulously selected from verified and certified sources due to the fact that along with the bioactive compounds, it can also contain toxic compounds (e.g., heavy metals) (6).

Skin cancers are malignancies most often developed by people with lighter skin and the incidence is steadily increasing, especially due to uncontrolled exposure to ultraviolet radia- 


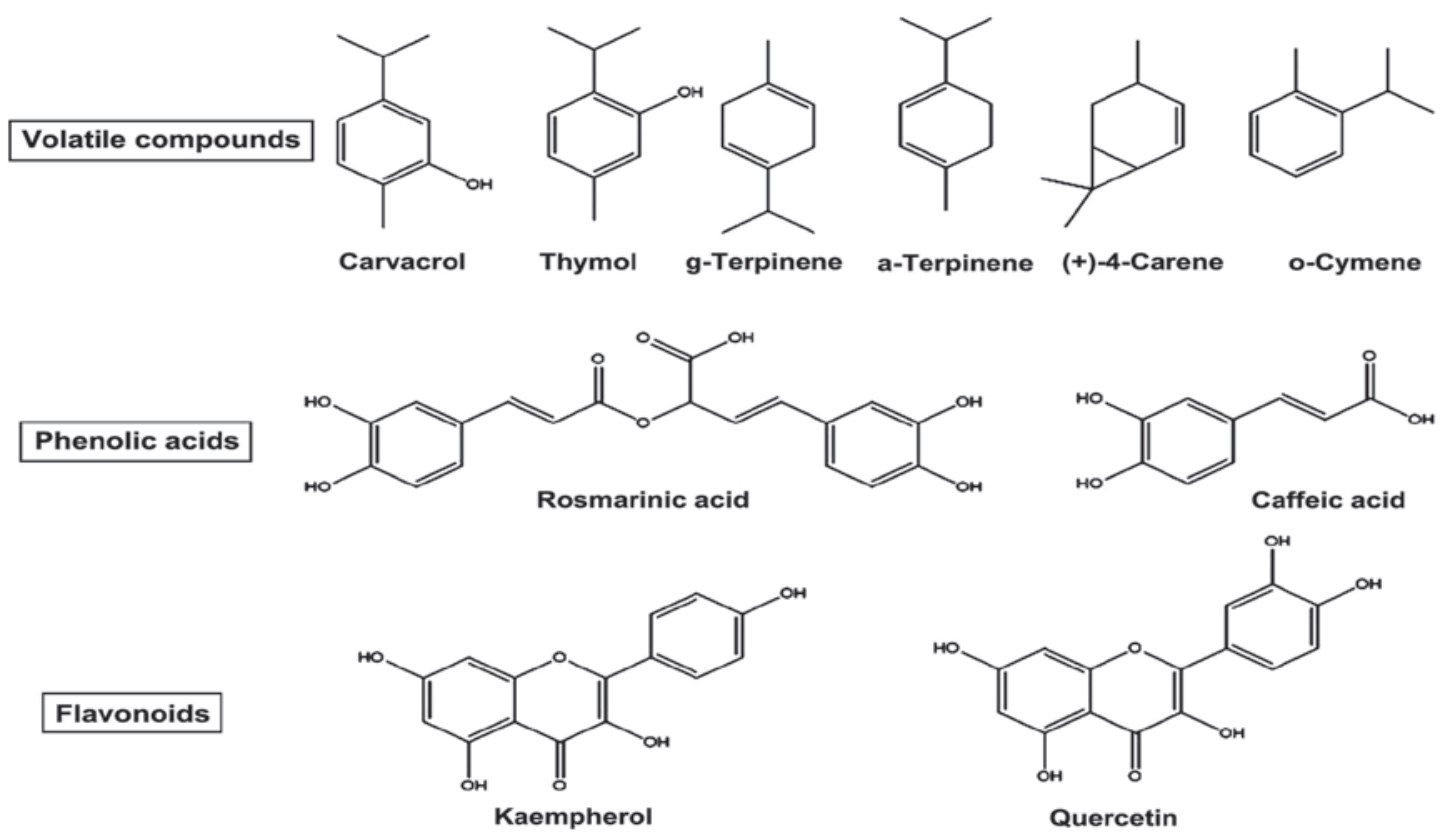

Figure 1. Representative examples of the main classes of compounds detected in Satureja hortensis L.

tion, recognized carcinogens (7). Skin cancers are divided into two major classes: non-melanoma cancers, the most common types diagnosed and melanoma cancers, the most aggressive with the lowest life expectancy after diagnosis $(8,9)$.

The present study was aimed to characterize the biological activity of essential/volatile oil (VO) in comparison with the total hydro-alcoholic extract (TE) in terms of in vitro experiments, namely: antioxidant activity (AOA), antibacterial and antifungal activity, and cytotoxicity on two normal cell lines (HaCaT, immortalized human keratinocytes; 1BR3, human skin fibroblasts) and two melanoma cell lines (A375, human melanoma; B16 melanoma 4A5, mouse melanoma) (Fig. 2).

\section{Materials and methods}

Plant material and reagents. Satureja hortensis L. (summer savory) from spontaneous flora was collected in Timis County (western region of Romania) during growing season of the year 2017. Botanical identification of the plant was realized by Professor Diana Antal, at the Department of Pharmaceutical Botany, Faculty of Pharmacy, 'Victor Babes' University of Medicine and Pharmacy (Timisoara, Romania) and a voucher specimen (no. CD_004) is deposited at the Herbarium of the Faculty. The plants were harvested at the time when the volatile oil content was at the maximum percentage regarding the volatile compounds of interest, namely at full flowering stage, and were dried in oven at $42^{\circ} \mathrm{C}$. Before processing, the plant material was crushed using an analytical laboratory mill (A 11 basic Analytical Mill; IKA Werke, Staufen, Germany). All standard compounds, reagents and solvents used for LC-MS analysis were purchased from Sigma-Aldrich; Merck KGaA (Darmstadt, Germany). The reagents used for antioxidant activity (AOA) assessment were ethanol 96\% (v/v) from Chemical Company S.A. (Iasi, Romania), 2,2-diphenyl1-picrylhydrazyl (DPPH) from Sigma Aldrich; Merck KGaA and ascorbic acid from Lach-Ner, Ltd. (Neratovice, Czech Republic).

Extraction procedures. Plant material (aerial parts, $250 \mathrm{~g}$ ) carefully selected and dried was subjected to hydro distillation method for three hours, using an all glass Clevenger-type apparatus according to the well-known methods described in the literature (10). The final product obtained was dried and stored at $-20^{\circ} \mathrm{C}$ until further analysis.

In order to obtain summer savory total TE Soxhlet extraction method was employed. Aerial parts (50 g), crushed and homogenized, were placed in the Soxhlet apparatus (Solvent Extractor $^{\mathrm{TM}}$, SER 148 Series; Velp Scientifica, Usmate, Italy) and $400 \mathrm{ml}$ of $70 \% \mathrm{EtOH}$ were used to sequentially extraction for $48 \mathrm{~h}$. The final extract was filtered through filter paper, the solvent was removed by a rotary evaporator (Heidolph Hei-VAP Advantage Rotary Evaporator package) under vacuum, the pellet being lyophilized and stored in a dark glass tube at $-20^{\circ} \mathrm{C}$ until further analysis.

Chemical composition of VO and TE.

GC-MS analysis. The chemical characterization of essential oil was realized by using a gas-chromatograph equipment with mass spectrometer (GS/MS)-QP2010 Plus (Shimadzu, Tokyo, Japan) with a capillary column with the characteristics: DB-WAX, $30 \mathrm{~m}$ length x $0.32 \mathrm{~mm} \times 1 \mu \mathrm{m}$. The carrier gas used was helium with a flow rate of $1 \mathrm{ml} / \mathrm{min}$. The program used for the compounds separation was: start at $40^{\circ} \mathrm{C}$ and increased with a rate of $5^{\circ} \mathrm{C} / \mathrm{min}$ to $250^{\circ} \mathrm{C}$ and hold for $5 \mathrm{~min}$. Injector and ion source temperatures were 250 and $220^{\circ} \mathrm{C}$, respectively. The injection volume was $1 \mu \mathrm{l}$ at a split ratio of 1:50. The NIST 02 database (webbook.nist.gov), integrated in the device software was used to identify volatile compounds. The percentages of individual components were calculated based on GC peak areas without using correction factors. The 


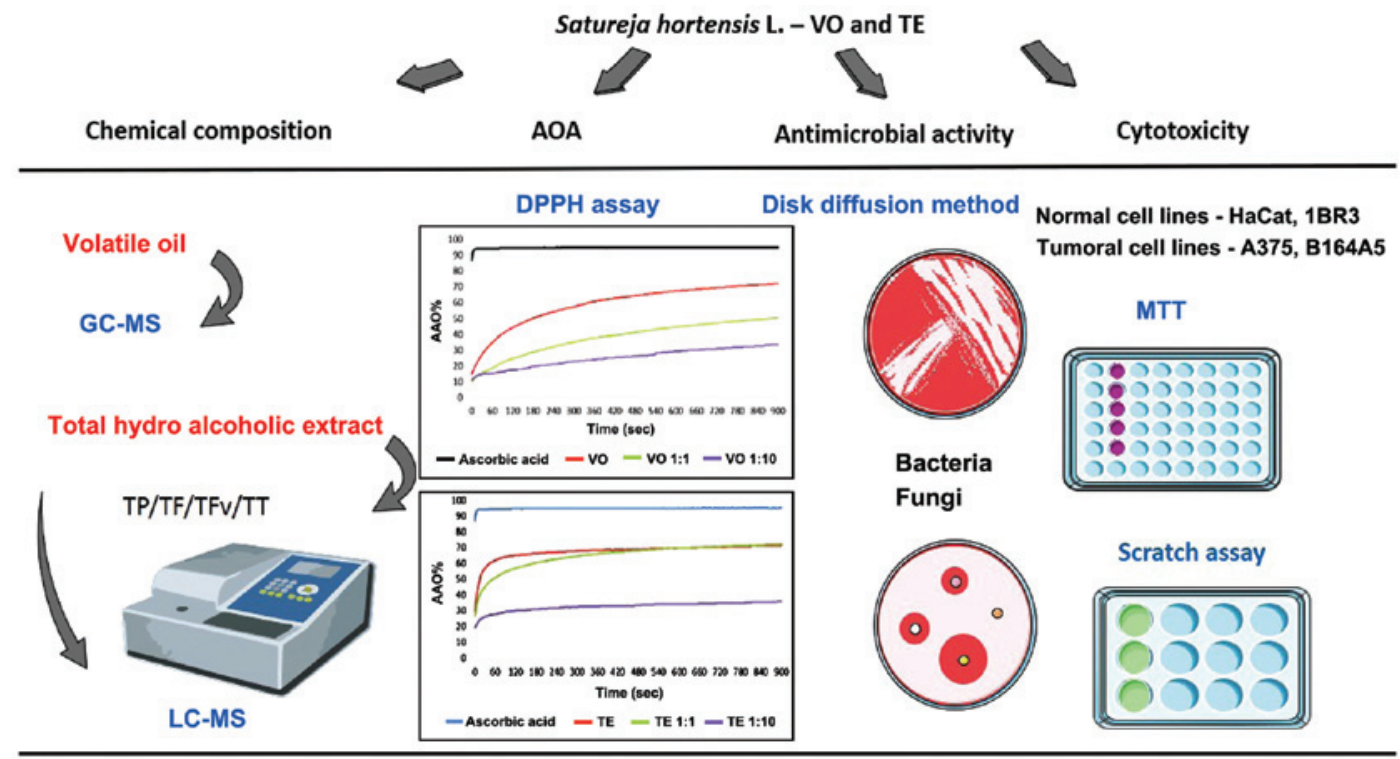

Figure 2. Schematic overview of the techniques applied to assess the biological activity of Satureja hortensis L. essential/VO in comparison with the TE. VO, volatile oil; TE, total hydro-alcoholic extract; AOA, antioxidant activity; TP, total polyphenols, TF, total flavonoids, TFv, total flavonols; TT, total codensed tannins; HaCaT, human immortalized keratinocytes; 1BR3, skin normal fibroblast; A375, human melanoma; B164A5, mouse melanoma.

linear retention indices (LRI) were determined under the same operating conditions in relation to a homologous series of n-alkanes (C8-C24) according to Van den Dool and Kratz (11):

$$
L R I=100 \times n+\frac{100 \times\left(t_{x}-t_{n}\right)}{t_{n+1}-t_{n}}
$$

where $t_{n}$ and $t_{n+1}$ are the retention times of the reference n-alkane hydrocarbons eluting immediately before and after chemical compound ' $\mathrm{X}$ ' and $\mathrm{t}_{\mathrm{x}}$ is the retention time of compound ' $\mathrm{X}$ '.

Total polyphenols, flavonoids, flavonols, and tannins. The total phenols (TP) evaluation was realized using Folin-Ciocalteu method as described in the literature (12). Samples $(0.5 \mathrm{ml})$ were treated with $1.25 \mathrm{ml}$ Folin-Ciocalteu reagent (Sigma-Aldrich; Merck KGaA) diluted 1:10 with water and incubated for $5 \mathrm{~min}$ at room temperature. After the addition of $1 \mathrm{ml}$ sodium carbonate $60 \mathrm{~g} / \mathrm{l}$ the samples were heated for $30 \mathrm{~min}$ at $50^{\circ} \mathrm{C}$ and then the sample absorbance was measured at $750 \mathrm{~nm}$ using an UV-VIS spectrophotometer (Specord 205; Analytik Jena AG, Jena, Germany). The calibration curve was obtained using gallic acid (GA) (Sigma-Aldrich; Merck KGaA) as positive control, in concentration of $0.03-1 \mathrm{mg} / \mathrm{ml}$. The results were expressed in mg GAE/g dry material (DM).

Flavonoids/flavonols (TF/TFv) content was evaluated by using classical test (Al colorimetric analysis) according to method described in the literature, dilution 1:1, at room temperature (13). Briefly, for flavonoid content $500 \mu 1$ of extract was treated with $500 \mu \mathrm{l} \mathrm{AlCl}{ }_{3}$ solution $2 \%$ (incubation for $30 \mathrm{~min}$ ) and absorbance values measured at $417 \mathrm{~nm}$. For flavonols content, same volume of extract was mixed with $\mathrm{AlCl}_{3}(2 \%)$ and $\mathrm{CH}_{3} \mathrm{COONa}(5 \%)$ (incubation for $3 \mathrm{~h}$ ) and absorbance values measured at $445 \mathrm{~nm}$. An Secomam UviLine 9400 Spectrophotometer (Kisker Biotech GmbH and Co., KG, Steinfurt, Germany) was used for all determinations and rutin was utilized as reference standard while the data are expressed as rutin equivalents (REs).
The total condensed tannin (TT) was determined by the vanillin test (14) slightly modified: Extract $(500 \mu \mathrm{l})$ was treated for several minutes, in an ice bath, with $1.5 \mathrm{ml}$ vanillin solution (1\% in dilute sulphuric acid) (incubation for $15 \mathrm{~min}$ ) and the absorbance was read at $500 \mathrm{~nm}$ on UviLine 9400 Spectrophotometer. The TT was expressed as milligrams of (+)-catechin equivalents (mg CE/g extract). All experiments were performed in triplicate.

LC-MS analysis. Quantification of individual phenolic compounds was performed using a Shimadzu chromatograph equipped with SPD-10A UV and LC-MS 2010 detectors (Schimadzu, Tokyo, Japan), and EC 150/2 Nucleodur C18 Gravity SB (MACHEREY-NAGEL GmbH \& Co., KG, Düren, Germany), $150 \times 2 \mathrm{~mm} \times 5 \mu \mathrm{m}$ column. Chromatographic conditions were as follows: mobile phase A, water acidified with formic acid at $\mathrm{pH}$ 3.0. Mobile phase B, acetonitrile acidified with formic acid at $\mathrm{pH} 3.0$, gradient program: $0.01-20 \mathrm{~min}, 5 \%$ phase B; 20.01-50 $\mathrm{min}, 5-40 \%$ phase B; $5-55 \mathrm{~min}, 40-95 \%$ phase B; and $55-60 \mathrm{~min}, 95 \%$ phase B. Solvent flow rate of $0.2 \mathrm{ml} / \mathrm{min}$, temperature at $20^{\circ} \mathrm{C}$. The monitoring wavelengths were 280 and $320 \mathrm{~nm}$. The calibration curves were performed in the range of $20-50 \mu \mathrm{g} / \mathrm{ml}$. The limit of quantification (LOQ), representing the lowest concentration for which $\mathrm{S} / \mathrm{N} \geq 5$, was $0.3 \mu \mathrm{g} / \mathrm{ml}$. Determinations were performed in duplicate. All reagents and solvents used were analytical grade chemicals. Standards were purchased from Sigma-Aldrich; Merck KGaA.

Antioxidant activity. The DPPH assay was applied to estimate the radical-scavenging ability of the tested samples. Briefly, $500 \mu \mathrm{l}$ of test sample was diluted with $2 \mathrm{ml}$ hydro-alcohol mixture (ethanol 50\%) and $500 \mu \mathrm{l}$ of DPPH $1 \mathrm{mM}$ was added. The absorbance was continuously measured at $516 \mathrm{~nm}$ with a T70 UV/VIS Spectrophotometer (PG Instruments Ltd., Leicestershire, UK) for $900 \mathrm{sec}$ to observe the changes in the values of AOA. The antioxidant activity recorded was 
compared in each case to that of ascorbic acid, used as positive control. The percent of AOA activity (\%) of each sample was calculated according to the formula used in our previous studies $(13,15)$.

\section{Antimicrobial activity}

Disc diffusion assay. Extracts of Satureja hortensis L. were tested for antimicrobial activity against Staphylococcus aureus (ATCC 25923 ${ }^{\mathrm{TM}}$ ), Bacillus cereus (ATCC 8035 ${ }^{\mathrm{TM}}$ ), Escherichia coli (ATCC 25922 ${ }^{\mathrm{TM}}$ ), Pseudomonas aeruginosa (ATCC 27853 ${ }^{\mathrm{TM}}$ ), Shigella flexneri (ATCC 12022 ${ }^{\mathrm{TM}}$ ), Salmonella typhimurium (ATCC 14028 ${ }^{\mathrm{TM}}$ ), Streptococcus pyogenes (ATCC $19615^{\mathrm{TM}}$ ) and for antifungal activity against Candida albicans (ATCC 10231 ${ }^{\mathrm{TM}}$ ) and Candida parapsilosis (ATCC 22019 ${ }^{\mathrm{TM}}$ ) (all from American Type Culture Collection, Manassas, VA, USA) using the Disk diffusion method for susceptibility testing, according to the Standard Rules for Antimicrobial Susceptibility Testing using Impregnated Disks.

In vitro testing was performed in plates, and microtablets with Gentamicin (for the antimicrobian activity) and Nystatin (for the antifungal activity) were used as positive controls. Commercial Gentamicin discs (10 mg, ref. E110712; BioMaxima, Lublin, Poland) and Nystatin (100 mg - ref. SD 025; Himedia, Mumbai, Maharashtra, India), alongside filter papers impregnated with a water:ethanol mixture (as negative controls) and filter papers impregnated with a known quantity of samples were assessed. A $10^{-2}$ dilution of the fresh fungi cultures and a $10^{-3}$ fresh bacteria cultures were used to perform the assay, an inoculum equivalent to a $0.5 \mathrm{McF}$ arland standard. The Petri plates, prepared by a method previously described $(16,17)$ were seeded and the respective specimens were treated with the VO $(10 \mu \mathrm{l} / \mathrm{disk})$ and TE $(250 \mu \mathrm{g} / \mathrm{disk})$, respectively and were incubated at $30^{\circ} \mathrm{C}$ for fungi and $37^{\circ} \mathrm{C}$ in case of bacteria, for $24-48 \mathrm{~h}$. Tests were performed in triplicate.

\section{In vitro cytotoxicity}

Cell lines and specific reagents. The cell lines used in this study: HaCaT, immortalized human keratinocytes (cat. no. 300493; CLS Cell Lines Service GmbH, Eppelheim, Germany), 1BR3, human skin fibroblasts (cat. no. 90011801; European Collection of Authenticated Cell Cultures, Salisbury, UK), A375, human melanoma cells (ATCC ${ }^{\circledR}$ CRL-1619 ${ }^{\mathrm{TM}}$ ), and B16 melanoma 4A5 cell line from mouse (ECACC; cat. no. 94042254) were acquired as frozen items and stored in liquid nitrogen until the experiment began. The 3-(4,5-dimethylthiazol-2-yl)2,5-diphenyltetrazolium bromide (MTT) kit was purchased from Roche Diagnostics GmbH (Mannheim, Germany). The reagents used for cell culture: Dulbecco's modified Eagle's medium (DMEM) was provided from ATTC and trypsin/ EDTA solution, phosphate-buffered saline (PBS), penicillin/ streptomycin mixture, fetal calf serum (FCS) and Trypan blue solution were supplied by Sigma-Aldrich; Merck KGaA.

Cell culture. Viability and migration assay. The impact of the samples on cell viability was tested on all four cell lines: HaCaT, 1BR3, human (A375) and murine (B164A5) melanoma cells. HaCaT, A375 and B164A5 cells were cultured in Dulbecco's modified Eagle's medium (DMEM), supplemented with $10 \%$ FCS and antibiotic mixture $(100 \mathrm{U} / \mathrm{ml}$ penicillin and $100 \mu \mathrm{g} / \mathrm{ml}$ streptomycin) and for 1BR3 cells was used
Table I. Chemical constituents of Satureja hortensis L. volatile oil (VO).

\begin{tabular}{|c|c|c|c|}
\hline Compounds & $\begin{array}{c}\text { LRI } \\
\text { reported in } \\
\text { literature (18) }\end{array}$ & LRI & $\begin{array}{c}\text { Concentration } \\
(\%)\end{array}$ \\
\hline$\alpha$-Thujene & $1022-1027$ & 1024 & 3.695 \\
\hline$\beta$-Pinene & $1105-1108$ & 1107 & 1.374 \\
\hline$\beta$-Myrcene & 1160 & 1159 & 3.931 \\
\hline (+)-4-Carene & $1149-1157$ & 1148 & 6.086 \\
\hline D-Limonene & 1196-1199 & 1198 & 0.558 \\
\hline$\beta$-Phellandrene & $1195-1212$ & 1207 & 0.361 \\
\hline$\gamma$-Terpinene & 1243 & 1245 & 37.862 \\
\hline$o$-Cymene & 1268 & 1267 & 15.113 \\
\hline$\alpha$-Thujone & $1433-1438$ & 1437 & 0.546 \\
\hline Camphor & $1490-1518$ & 1511 & 0.521 \\
\hline$\beta$-Caryophyllene & $1597-1618$ & 1602 & 1.496 \\
\hline $\begin{array}{l}\text { Bicyclo[5.1.0]octane, } \\
8 \text {-(1-methylethylidene })\end{array}$ & - & 1698 & 0.274 \\
\hline Anethole & $1817-1819$ & 1817 & 0.420 \\
\hline Octanoic acid & 2056-2084 & 2067 & 0.304 \\
\hline Thymol & $2162-2169$ & 2168 & 13.491 \\
\hline Isothymol & $2179-2225$ & 2183 & 0.645 \\
\hline Carvacrol & 2189 & 2188 & 13.225 \\
\hline Total & & & 99.902 \\
\hline
\end{tabular}

as culture medium the Eagle's Minimum Essential Medium (EMEM) supplemented with $15 \%$ FBS. The culture plates were incubated at $37^{\circ} \mathrm{C}$ in a humidified atmosphere with $5 \% \mathrm{CO}_{2}$, and passaged every day. Cell counting was performed with Countess $^{\mathrm{TM}}$ II Automated Cell Counter (Thermo Fisher Scientific, Inc., Waltham, MA, USA) in Trypan blue presence.

MTT assay is a colorimetric assay which was performed for cell viability evaluation. The viability percentage is directly proportional with the mitochondrial reduction of viable cells which will convert MTT to formazan via succinic dehydrogenase activity. Briefly, $10^{4}$ cells/well were plated onto a 96-well plate in $200 \mu \mathrm{l}$ media and incubated until $90 \%$ confluence was reached. The cells were stimulated with $100 \mu \mathrm{l}$ media containing 5, 10, 25, 50, and $100 \mu \mathrm{M}$ (for $\mathrm{VO}$ based on the molecular weight of $\gamma$-terpinene and for TE based on the molecular weight of rosmarinic acid) of test samples. A volume of $10 \mu \mathrm{l} \mathrm{MTT} /$ well was added at $24 \mathrm{~h}$ post stimulation and the mitochondrial reduction of the tetrazolium salt (MTT) to formazan was determined after a $4 \mathrm{~h}$ contact time. The concentration of formazan was measured at $570 \mathrm{~nm}$ wavelength, via spectrophotometry with a microplate reader (xMark $^{\mathrm{TM}}$ Microplate; Bio-Rad Laboratories, Inc., Hercules, CA, USA).

The migratory character of the tumor cells used in this study was examined by applying scratch assay technique. In brief, $2 \times 10^{5}$ cells/well were seeded in 12-well plates in specific culture medium and when the confluence was appropriate $(85-90 \%)$ a gap was drawn in the middle of the well with a $10 \mu \mathrm{l}$ tip. The capacity of the cells to migrate and fill the 
Table II. Total content of different bioactive classes from Satureja hortensis L. total hydro alcoholic extract (TE) determined by spectrophotometric method.

\begin{tabular}{lccccc}
\hline Sample & Extraction yield (\%) & TP (mg GAE/g DM) & TF (mg RE/g DM) & TFv (mg RE/g DM) & TT (mg CE/g DM) \\
\hline TE & 28.4 & $164.75 \pm 2.47$ & $24.04 \pm 1.26$ & $6.65 \pm 0.41$ & $16.23 \pm 0.94$ \\
\hline
\end{tabular}

gap was monitored for $24 \mathrm{~h}$ by acquiring images at different time-points, namely 0,3 and $24 \mathrm{~h}$ using an Optika Microscopes Optikam Pro Cool 5 and Optika View (Optika, Ponteranica, Italy).

Statistical analysis. The GraphPad Prism 7 software (GraphPad Software, San Diego, CA, USA) was employed for the description and performance of the data. One-way ANOVA followed by Tukey's multiple comparisons test was used to determine the statistical differences between the various experimental and control groups $(\mathrm{P}<0.05, \mathrm{P}<0.01$, and $\mathrm{P}<0.0001)$. The results were expressed as the mean \pm standard deviation (SD).

\section{Results}

Chemical composition of $V O$ and TE. The chemical composition of Satureja hortensis L. VO is presented in Table I. A number of 18 compounds were identified in total, and the main compounds were: $\gamma$-terpinene (37.862\%), $o$-cymene (15.113\%), thymol (13.491\%), carvacrol (13.225\%), (+)-4-carene (6.086\%), $\beta$-myrcene (3.931\%), $\alpha$-thujene (3.695\%), $\beta$-caryophyllene $(1.496 \%), \beta$-pinene $(1.374 \%)$, isothymol $(0.645 \%)$, D-limonene (0.558\%), $\alpha$-thujone $(0.546 \%)$ and camphor $(0.521 \%)$.

The resulting hydro alcoholic extract of summer savory was evaluated for total phenols, flavonoids, flavonols, and condensed tannins contents with the help of spectrophotometric methods and the results are presented in the Table II.

Individual quantitative analysis of polyphenols, revealed the chemical composition found in the total hydro alcoholic extract of Satureja hortensis L., quercetin and kaempherol being the major compounds. Moreover, a number of phenolic acids (caffeic, gallic, rosmarinic, coumaric, ferullic, and protocatechuic), stilbenoid (resveratrol), flavonoid aglycones (epicatechin), and glycosides (rutin) were identified in the extract. The identity of the compounds was certified by LC-MS by comparison with standards. The polyphenols identified in composition of summer savory TE are presented in Table III.

Antioxidant activity. The Fig. 3 presents the AOA of the summer savory VO and TE which proved to possess a high activity compared to the one of positive control used, ascorbic acid. For the evaluation, three samples from each type were analyzed: VO crude sample, VO 1:1 dilution and VO 1:10 dilution and TE crude sample, TE 1:1 dilution and TE 1:10 dilution, respectively. VO samples showed a steady increase throughout the entire time period. Thus, the AOA values after the first $300 \mathrm{sec}$ were: VO, 57.35\%; VO 1:1, 34.98\%; and VO 1:10, $22.83 \%$ while at the end of period $(900 \mathrm{sec})$ the values were: VO, 72.12\%; VO 1:1, 50.37\%; and VO 1:10,33.73\%. In the case of TE samples, data recorded revealed AOA as follows: after the first $300 \mathrm{sec}$ TE, 67.86\%; TE 1:1, 64.56\%; and TE 1:10,
Table III. The main polyphenols of Satureja hortensis L. total extract (TE).

\begin{tabular}{lccc}
\hline Compounds & Retention time & $\mathrm{m} / \mathrm{z}$ & $\begin{array}{c}\text { Concentration } \\
(\mu \mathrm{g} / \mathrm{g})\end{array}$ \\
\hline Gallic acid & 4.8 & 169 & 28.39 \\
Protocatechuic acid & 10.8 & 153 & 8.3 \\
Caffeic acid & 21.9 & 179 & 29.12 \\
Epicathechin & 22.7 & 289 & 171.65 \\
Coumaric acid & 24.4 & 163 & 4.15 \\
Ferullic acid & 24.7 & 193 & 29.14 \\
Rutin & 25.7 & 609 & 187.45 \\
Rosmarinic acid & 28.8 & 359 & 121.05 \\
Resveratrol & 31.9 & 227 & 44.00 \\
Quercetin & 32.1 & 301 & 480.04 \\
Kaempherol & 34.9 & 285 & 3518.99 \\
\hline
\end{tabular}

$32.42 \%$ while at the end of period assessed $(900 \mathrm{sec}) \mathrm{TE}$, $71.38 \%$; TE 1:1, 72.19\%; and TE 1:10, 35.77\%. The graphs prove that TE and TE 1:1 possesses the highest increase, especially in the first seconds followed by VO.

Antimicrobial activity. In Table IV are presented the data obtained after the antimicrobial activity evaluation. The results showed that VO, used in concentration of $10 \mu \mathrm{l} / \mathrm{disk}$, exhibits an antibacterial effect against both Gram positive and Gram negative bacteria, respectively and also an antifungal effect. The most pronounced antibacterial effect was against Gram positive bacteria $S$. aureus $(16 \mathrm{~mm})$ and the weakest against Gram negative bacteria S. flexneri and Gram positive bacteria S. pyogenes $(8 \mathrm{~mm})$ while the antifungal effect was recorded only against $C$.albicans $(10 \mathrm{~mm})$. TE, used in concentration of $250 \mu \mathrm{g} /$ disk, exhibited only a slight effect against $S$. flexneri, S. typhimurium and S. pyogenes while no antifungal effect was recorded.

Cell viability. In order to assess the effects induced by VO and TE on A375 and B16 melanoma 4A5 cell viability, different concentrations $(5,10,25,50$ and $100 \mu \mathrm{M})$ were tested in a $24 \mathrm{~h}$ exposure. The results revealed that: i) VO induced a significant decrease of A375 living cells percentage at low concentrations, ii) the effect was dose-dependent, and iii) the concentrations lower than $25 \mu \mathrm{M}$ were more toxic for the cells (Fig. 4). The $\mathrm{IC}_{50}$ value was $22.27 \mu \mathrm{M}$, which proves the potent inhibitory effect of VO on A375 cells viability. The evaluation of TE revealed a reduced viability percentage of A375 cells, but much lower compared to $\mathrm{VO}\left(\mathrm{IC}_{50}\right.$ value for TE was $40.38 \mu \mathrm{M})$. The viability rate (\%) of A375 cells decreased at 
Table IV. Antimicrobial and antifungal activities of the volatile oil and total hydro alcoholic extract from Satureja hortensis L. by Disk Diffusion method, expressed as diameter $(\mathrm{mm})$ of inhibition zone (mean $\pm \mathrm{SD})$ including the disc diameter $(6 \mathrm{~mm})$.

\begin{tabular}{|c|c|c|c|c|}
\hline Bacteria and fungi & $\mathrm{VO}(\mathrm{mm})$ & $\mathrm{TE}(\mathrm{mm})$ & $\begin{array}{l}\text { Positive control } \\
\text { (antibiotic, } \mathrm{mm} \text { ) }\end{array}$ & $\begin{array}{c}\text { Negative control } \\
\text { (solvent) }\end{array}$ \\
\hline \multicolumn{5}{|l|}{ Bacteria } \\
\hline S. aureus, ATCC 25923(+) & $16 \pm 0.58$ & - & 15 & - \\
\hline E. coli, ATCC 25922(-) & $9 \pm 0.50$ & - & 12 & - \\
\hline P. aeruginosa, ATCC 27853(-) & $10 \pm 0.61$ & - & 15 & - \\
\hline B.cereus, ATCC 8035(+) & $12 \pm 0.71$ & - & 15 & - \\
\hline S.flexneri, ATCC 12022(-) & $8 \pm 0.36$ & $8 \pm 0.21$ & 13 & - \\
\hline S.typhimurium, ATCC 14028(-) & $11 \pm 0.41$ & $8 \pm 0.26$ & 12 & - \\
\hline S.pyogenes, ATCC 19615(+) & $8 \pm 0.35$ & $7 \pm 0.25$ & 21 & - \\
\hline \multicolumn{5}{|l|}{ Fungi } \\
\hline C.albicans, ATCC 10231 & $10 \pm 0.54$ & - & 12 & - \\
\hline C. parapsilosis, ATCC 22019 & - & - & 13 & - \\
\hline
\end{tabular}
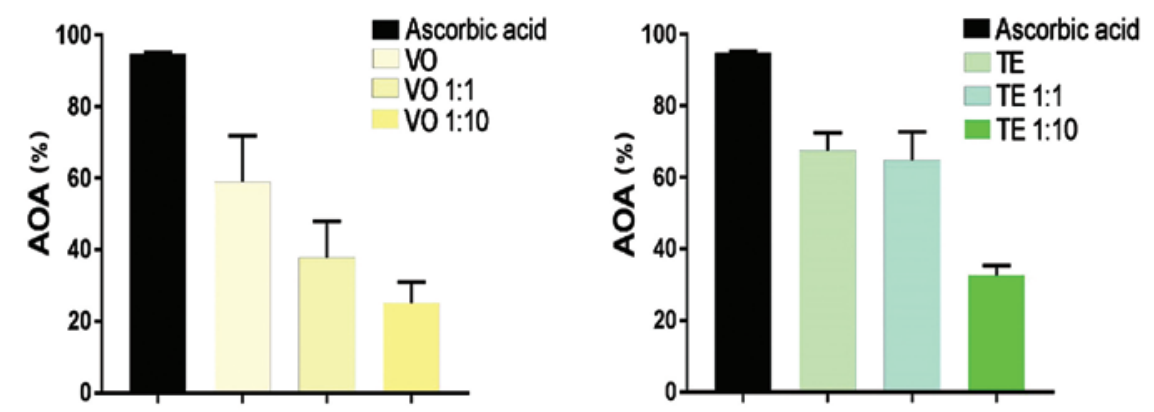

Figure 3. Antioxidant activity of Satureja hortensis L. volatile oil (VO) and total hydro alcoholic extract (TE) obtained from aerial parts after the first 300 sec.

concentrations lower than $25 \mu \mathrm{M}$, whereas the highest concentration tested of $100 \mu \mathrm{M}$ did not affect the cells $(91.22 \pm 0.27 \%$ viable cells) (Fig. 4).

The B164A5 cells also seemed to be sensitive to VO effect $\left(\mathrm{IC}_{50}, 34.16 \mu \mathrm{M}\right)$. The media percentages of viable cells at low concentrations of 5 and $10 \mu \mathrm{M}$ have been reduced, but not in the same manner as in the case of A375 cells ( $5 \mu \mathrm{M}$ : $60.55 \pm 1.28$ vs. $36.18 \pm 1.51$ and $10 \mu \mathrm{M}$ : $63.26 \pm 1.83$ vs. $42.14 \pm 2.06$, respectively). TE induced a lower decrease of living cell percentage in the case of B164A 5 cells as compared to the one determined for A375 cells, the calculated $\mathrm{IC}_{50}$ value being $204.4 \mu \mathrm{M}$ with a non-significantly reduced percentage of viable cells at $100 \mu \mathrm{M}$ (94.46 \pm 0.87 ) (Fig. 4).

On normal human keratinocyte and fibroblasts, the concentrations of VO and TE used did not show a significant toxicity, whereas a potent dose-dependent stimulatory effect was observed (Fig. 5). In the case of keratinocytes, TE had a low cytotoxic effect on cell viability at the lowest concentrations ( $~ 82 \%$ at $5 \mu \mathrm{M}$ and $\sim 86 \%$ at $10 \mu \mathrm{M}$, viable cells), while volatile oil exerted a weak stimulating effect at the highest concentrations used. Human fibroblasts were affected in terms of viability, only by small sample concentrations, for both VO $(\sim 93 \%$ at $5 \mu \mathrm{M})$ and TE $(\sim 90 \%$ at $5 \mu \mathrm{M})$, respectively whereas highest concentrations of VO utilized presented a strong stimulatory effect $(120 \%$ at $50 \mu \mathrm{M}$ and $\sim 116 \%$ at $100 \mu \mathrm{M})$.
Cell morphology. Since the test compounds (VO and TE), exhibited a significant cytotoxic effect against tumor cells A375 and B164A5, the impact of these compounds on cell morphology was monitored by light microscopy (Optikam Pro Cool 5; Optika Microscopes, Ponteranica, Italy). In the case of A375, the control cells (unstimulated) displayed a normal epithelial morphology, with spindle and cobblestone shapes, strongly bound and adherent to culture plate, and highly confluent after $24 \mathrm{~h}$. The A375 cells stimulated with $\mathrm{VO}$ and TE for $24 \mathrm{~h}$ did not present differences in terms of morphology, still a reduced confluence and loose bonds was detected between the cells as compared to control cells, and several cells were floating in the culture medium (Fig. 6). B164A5 control cells presented a healthy fibroblastic-like morphology, with polygonal shape, increased adherence to culture plate and confluence at $24 \mathrm{~h}$. The VO and TE stimulation led to several changes in cell shape, becoming shrunken with a reduced confluence tendency and started to detach from the culture plate (Fig. 6), results that confirm the data recorded for cell viability tests.

Cell migration and proliferation. Based on the results obtained for the cell viability test, the effects of VO and TE on cell migration were assessed by using only the concentrations that did not induce a significant cell death of the cells $(25 \mu \mathrm{M})$. The 

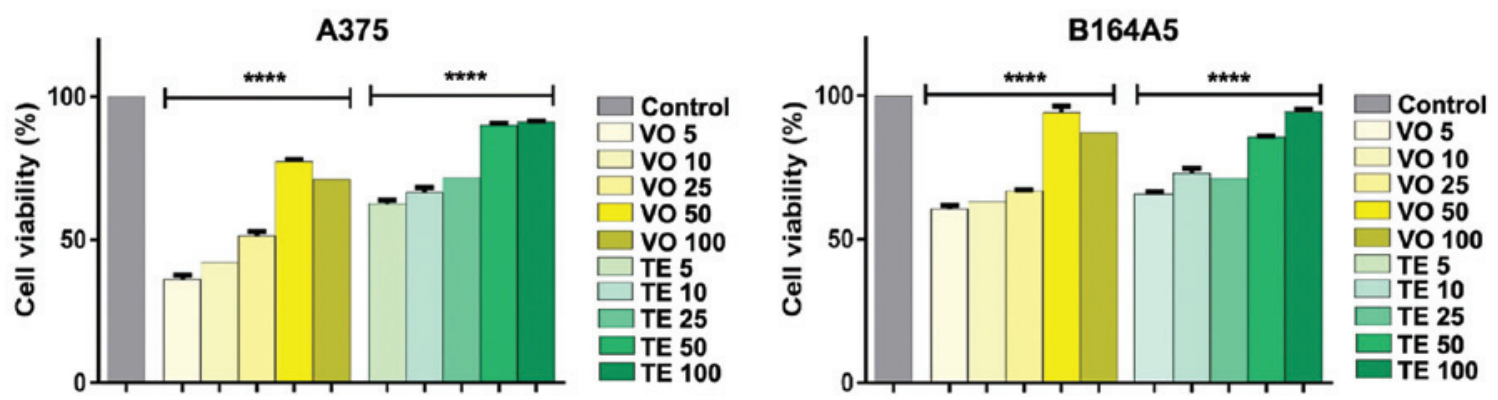

Figure 4. Viability percentage of A375-human melanoma and B16 melanoma 4A5 cells at 24 h post-stimulation with samples (5, 10, 25, 50 and 100 $\mu \mathrm{M})$. The results are expressed as cell viability percentage $(\%)$ normalized to control cells. ${ }^{* * * * *} \mathrm{P}<0.0001$ compared to control group.
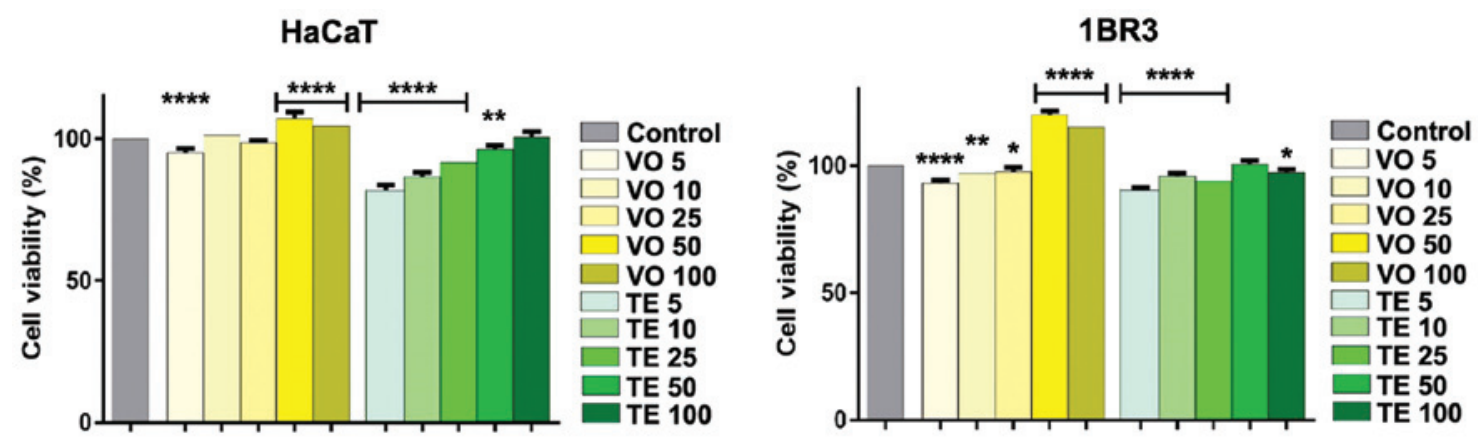

Figure 5. Viability percentage of HaCaT immortalized human keratinocytes and 1BR3 human skin cells at $24 \mathrm{~h}$ post-stimulation with samples $(5,10,25,50$ and $100 \mu \mathrm{M})$. The results are expressed as cell viability percentage (\%) normalized to control cells. ${ }^{*} \mathrm{P}<0.05,{ }^{* * *} \mathrm{P}<0.01,{ }^{* * * *} \mathrm{P}<0.0001$ compared to control group.

effect of the VO and TE on cell migration and proliferation was evaluated by the means of scratch assay, a wound healing type technique. After the scratches were drawn (when the confluence of the cells was higher than $85 \%$ ), the cells were stimulated for $24 \mathrm{~h}$. Images were taken at three different time-points, namely 0,3 , and $24 \mathrm{~h}$ in order to study the impact of the VO and TE on cell migration and proliferation.

The A375 control cells presented migratory capacity by covering the wound area after $24 \mathrm{~h}$ but in the case of cells treated with VO and TE an inhibition of the cell migration process was observed, more pronounced after $24 \mathrm{~h}$ (Fig. 7). Similar effects were detected in the case of B164A5 cells, but the effect exerted by VO was more pronounced (Fig. 8).

The VO did not affect the normal keratinocyte and fibroblast migration after $3 \mathrm{~h}$, neither after $24 \mathrm{~h}$, moreover, the sample had a stimulatory effect on cell proliferation. The cells were abundant on the plate and well attached. The TE induced a similar effect on $\mathrm{HaCaT}$ cell migration and proliferation as that described for VO: a stimulatory effect, results that were in agreement with the data recorded for the cytotoxicity test.

\section{Discussion}

A variety of factors can influence the chemical composition of Satureja hortensis L. essential oils including environmental factors, extraction and isolation procedures, and storage conditions $(19,20)$. To obtain the essential oil, the hydro distillation method was chosen due to the reduced time of obtaining, the facile way of preparation and the increased content of volatile compounds of interest. Sefdikon et al (19) noted that drying the aerial parts in the oven at $45^{\circ} \mathrm{C}$ and application of the above method represents the proper alternative for obtaining the desired yields (19). Studies regarding the chemical composition of essential oils obtained from the aerial parts of the plant harvested from different regions of the world showed that the main compounds are carvacrol, $\gamma$-terpinene, $p$-cymene, $\alpha$-terpinene and myrcene $(19,21,22)$. However, it should be mentioned that there is a lack of data in the literature regarding the chemical composition in terms of the region, cultivation conditions and environmental factors. Some authors mentioned that the percentages of carvacrol and terpinene are highly influenced by the climate, especially by ultraviolet radiation so they can lead to an increase in carvacrol content and a decrease in terpinene $(21,23)$. The data obtained in the present study is partly consistent with the literature, specifying that the percentages of the mentioned compounds decreased in the following order $\gamma$-terpinene $(\sim 38 \%)>o$-cymene $(\sim 15 \%)$ $>$ thymol $(\sim 13.5 \%)>$ carvacrol $(\sim 13 \%)$ as detailed in Table I.

As in the case of essential oil, the chemical composition of the extract varies depending on a number of factors, such as plant origin, harvest period, geographic and climatic factors, and extraction method. Chkhikvishvili et al (24) identified in the ethanolic extract of Satureja hortensis L. by HPLC analysis, a series of compounds: rosmarinic and ferulic acids were the major compounds, and caffeic, $p$-coumaric acids, catechin, epicatechin, luteolin, apigenin, rutin, hesperidin, and apigenin-7-glucoside were also detected (24). By applying Soxhlet extraction method and using $\mathrm{EtOH}, 96 \%$ as solvent, an extract concentrated in rosmarinic acid and quercetin was obtained, with lower concentrations of other polyphenols such as apigenin, kaempherol, luteolin, rutin, $p$-coumaric acid and chlorogenic acid (25). 

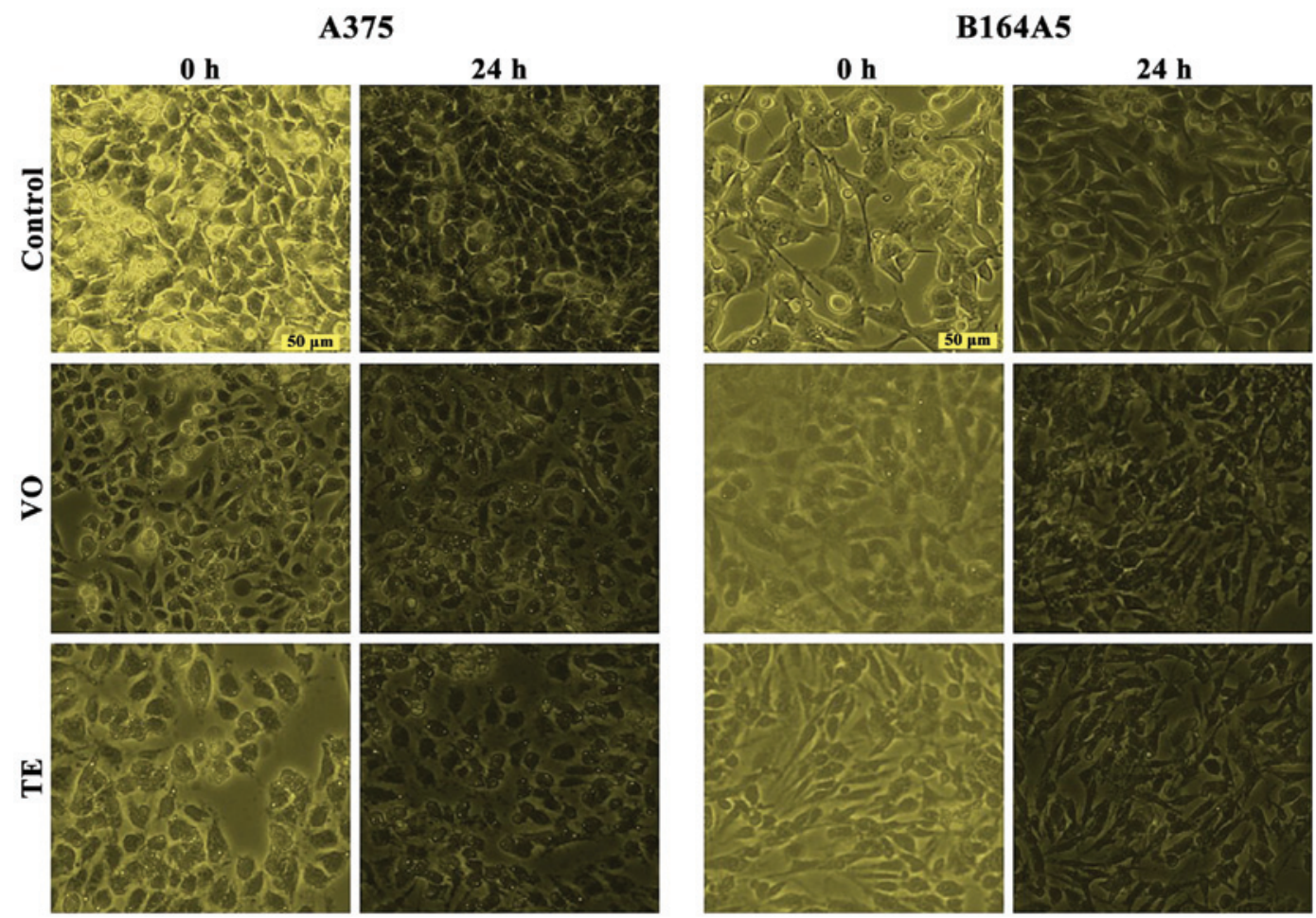

Figure 6. Morphological aspect of control A375 and B164A5 cells stimulated with Satureja hortensis L. volatile oil and total hydro alcoholic extract for $24 \mathrm{~h}$ at a concentration of $25 \mu \mathrm{M}$. Images were obtained by light microscopy at x 20 magnification. Scale bar, $50 \mu \mathrm{m}$.
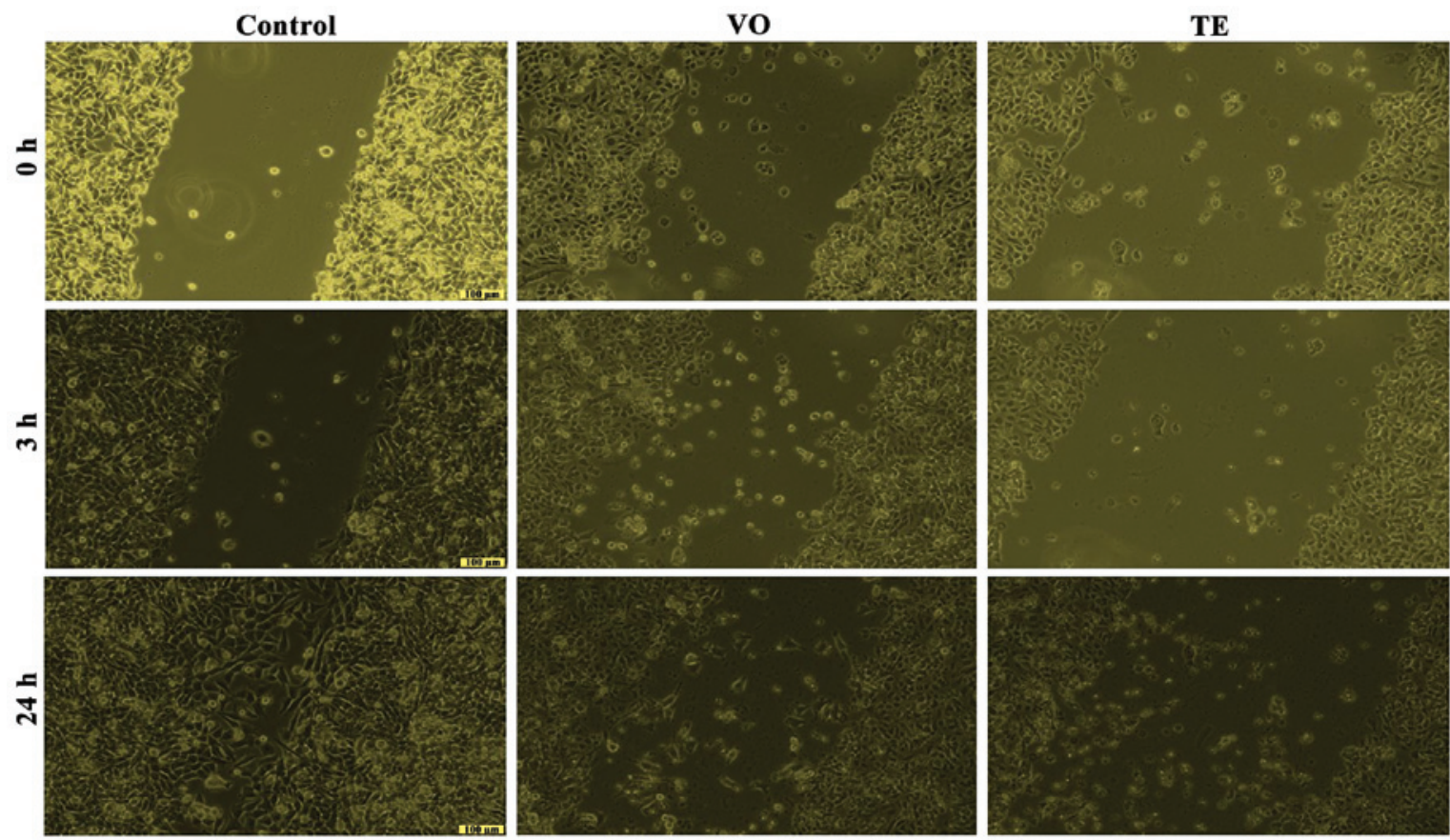

Figure 7. The effect of Satureja hortensis L. VO and TE on A375 cell migration and proliferation after stimulation with a concentration of $25 \mu \mathrm{M}$ at different time-points $(0,3$, and $24 \mathrm{~h})$ post-stimulation. Images were obtained by phase contrast microscopy at x10 magnification. Scale bar, $100 \mu \mathrm{m}$.

A number of causes, including a disorganized lifestyle, an inadequate diet or particular conditions developed by foreign stimuli lead to the formation of reactive oxygen species. Thus, peroxide (ROO•), hydroxyl (HO•), nitric oxide (NO•), superoxide anion $\left(\mathrm{O}_{2}{ }^{\circ}\right)$, hydrogen peroxide $\left(\mathrm{H}_{2} \mathrm{O}_{2}\right)$, and other free radicals are produced in vivo by partial reduction of $\mathrm{O}_{2}$ through mitochondrial respiration/oxidative phosphorylation as a protection mechanism. Increased production of these species most often lead to alterations in the DNA, proteins and lipids, with serious consequences on the body in terms of cellular aging, mutagenicity, carcinogenicity, and other (26).

Antioxidant compounds possess the ability to react in different conditions transferring electrons, binding metal ions, activating enzymes, reducing radicals and inhibiting oxidases, 

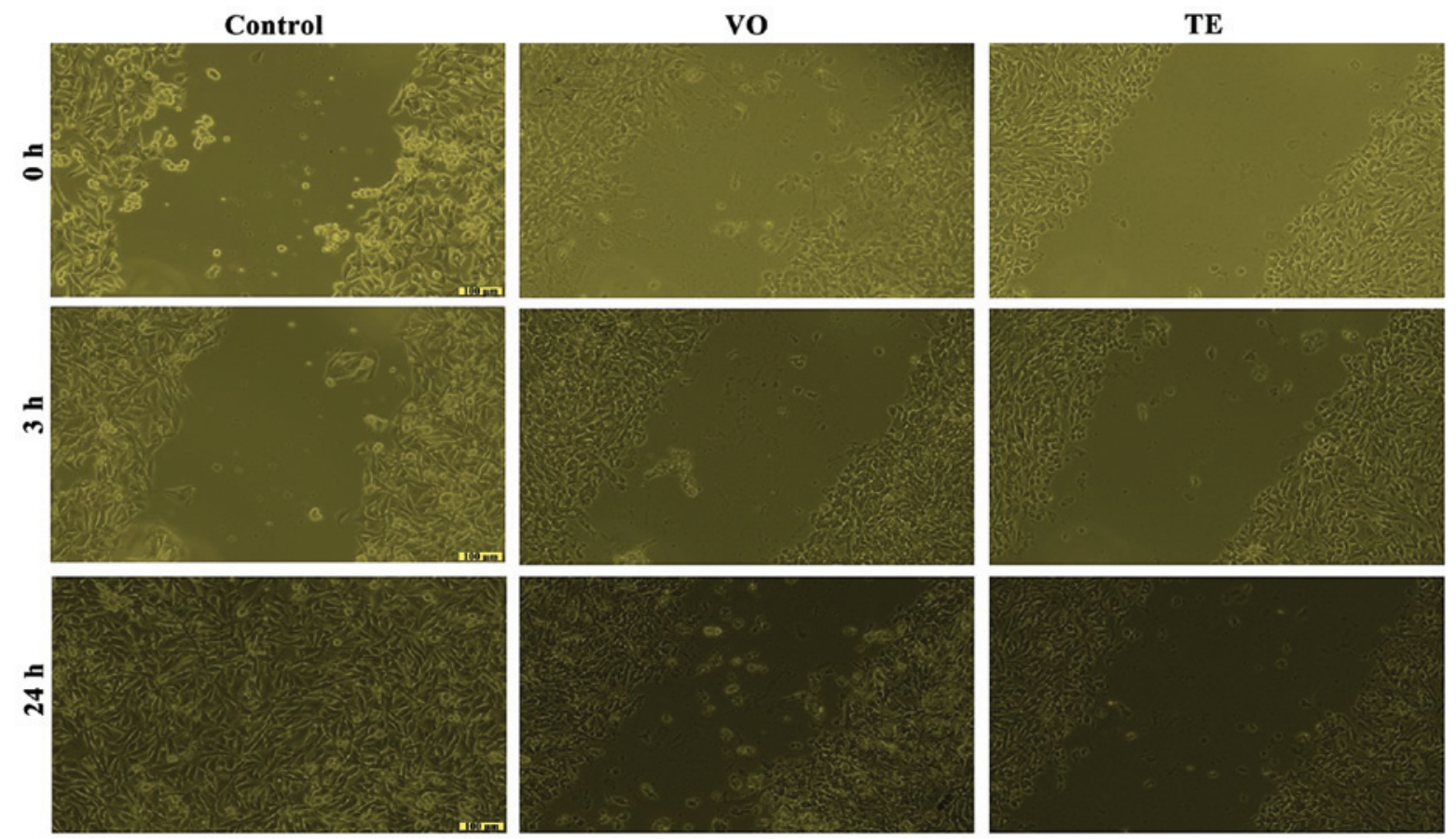

Figure 8. The effect of Satureja hortensis L. VO and TE on B164A5 cell migration and proliferation after stimulation with a concentration of $25 \mu \mathrm{M}$ at different time-points $(0,3$, and $24 \mathrm{~h})$ post-stimulation. Images were obtained by phase contrast microscopy at x10 magnification. Scale bar, $100 \mu \mathrm{m}$.

all of these leading to the neutralization of the reactive oxygen species (27). Two types of antioxidant compounds have been described, endogenous antioxidants naturally produced in the body and exogenous antioxidants which are found in different sources of natural origin (e.g., fruits, vegetables and plants). Antioxidant properties of $\mathrm{VO}$ and TE, were found to be significant; therefore, due to the rich content in compounds with antioxidant properties, which possess an increased number of $\mathrm{OH}$ groups capable of participating in the reactions mentioned above, their properties are explored in the study of certain pathologies.

Considering the antimicrobial activity, volatile oils exert some actions on cell membranes, such as interference and destabilization, with repercussions on the phospholipid bilayer and alteration of enzyme activity (28). The inhibitory effect against bacteria and fungi of summer savory VO can be attributed to the increased content of biologically active compounds of the monoterpenes class, especially terpinene, thymol and carvacrol (5). Some studies reported that thymol and carvacrol possess an increased activity against bacterial and fungal strains, while $\gamma$-terpinene and $p$-cymene are active against fungal strains $(29,30)$. Other data mention that thymol has an important inhibitory activity against $S$. aureus, carvacrol and $p$-cymene against $E$. coli and $\gamma$-terpinene against $S$. aureus and C.albicans (5). The volatile oil of Satureja hortensis L. possesses a wide antimicrobial spectrum, against both bacteria and fungi (25 bacteria, 8 fungi, and 1 yeast species) (31). Mihajilov et al (32) proved the activity against E. coli, S. typhimurium, S. aureus, L. monocytogenes, P. putida strain isolated from meat (32). In the present study both $\mathrm{VO}$ and TE were tested; $\mathrm{VO}$ showed activity against tested bacteria and fungi, with the indication that $S$. aureus was the most sensitive while TE exerts only a slight effect against three bacteria. These aspects are in agreement with the hypothesis that only the volatile oil has in its composition more antimicrobial compounds than the extracts (31).

Data related to the activity of different natural compounds, volatile oil or extract obtained from different medicinal plants have captured the attention in recent years and are extensively studied and tested in various cancer pathologies $(33,34)$. Extracts from Satureja hortensis L. on melanoma cells are scarce and also briefly described. In one study, Stanojković et al (35) tested the methanol extract of Satureja hortensis L. and observed a strong antitumor activity against Fem-x human malignant melanoma cells with an $\mathrm{IC}_{50}$ of $39.66 \pm 2.71 \mu \mathrm{g} / \mathrm{ml}$ (35). It was also proved that the extract highly inhibited the K562 cell viability at low concentrations of $10 \mu \mathrm{g} / \mathrm{ml}\left(\mathrm{IC}_{50}, 52 \mu \mathrm{g} / \mathrm{ml}\right)$, and in case of Jurkat cell line the $\mathrm{IC}_{50}$ value was $66.7 \mu \mathrm{g} / \mathrm{ml}$ (36). Another study showed that Satureja hortensis L. and its rosmarinic acid-rich fraction are able to protect Jurkat cells against oxidative stress caused by $\mathrm{H}_{2} \mathrm{O}_{2}$ (24). In the case of Hep2c, human cervix carcinoma, $\mathrm{RD}$, human rhabdomyosarcoma and L2OB, murine fibroblast cell lines, the calculated inhibitory concentrations were in the ranges of 13.23-35.29, 18.43-31.03 and 20.51-34.09 $\mu \mathrm{g} / \mathrm{ml}$, respectively for ethanolic summer savory extracts (25).

Multiple studies were focused on the chemical compounds found in the composition of volatile oil and extract. Common active principles of S. hortensis L. such as $\alpha$-pinene, $\gamma$-terpenene, caryophyllene and others, presented antiproliferative activity against K562 cells ( $\mathrm{IC}_{50}$ value between $98-329 \mu \mathrm{M} / \mathrm{ml}$ ) (37). Consequently, carvacrol exerted cytotoxic activity against breast cancer (MCF-7), skin cancer (SK-ML-2), colon cancer (HCT-15) and pancreatic cancer (MIAPaCa-2) (38); kaempherol presented antiproliferative activity $\left(\mathrm{IC}_{50}, 20 \mu \mathrm{M}\right)$ against human melanoma (A375) after $48 \mathrm{~h}$ incubation (39) and showed various suppressive effects on melanoma A375SM cells, at a concentration of $20 \mu \mathrm{M}(40)$; quercetin slightly decreased 
the survival of human melanoma cells (A375 and A2058) in a time- and dose-dependent manner with $\mathrm{IC}_{50}$ values of 99.6 and $118.1 \mu \mathrm{M}$ after $48 \mathrm{~h}$ treatment and the viability of murine melanoma cells (B16F10) decreased in a dose-dependent manner $(41,42)$; quercetin and other compounds from its class, such as epigallocatechin, kaempherol, myricetin and luteolin showed inhibitory actions on HGF-stimulated melanoma cell migration and invasion. These findings denoted that these compounds shared similar activities and may be taken into account in melanoma treatment and prevention (42).

The novelty of this study consists in the biological assessment of essential oil and total hydro-alcoholic of Satureja hortensis $\mathrm{L}$. both as individuals and in comparative terms. VO and TE of summer savory possessed different antimicrobial activity against tested bacteria and fungi. VO proved to be active against all tested bacteria, especially against $S$. aureus while TE showed poor activity against three of the tested bacteria (S. flexneri, S. typhimurium and S.pyogenes) with no activity on fungi. The antitumor activity against melanoma cells was present, and no toxic effects on healthy cell lines tested (immortalized human keratinocytes and human skin fibroblast) was recorded. VO showed a greater efficacy as compared to TE on human melanoma cells (A375) while in the case of murine melanoma cells (B164A5) the impact on cell viability was similar. The activity of the compounds tested was higher at low concentrations whereas at high concentrations the percentages of viability were increased. Further in vitro and in vivo studies are necessary in order to elucidate the anticancer mechanisms of activity, and for a better understanding of the role played by the biological active compounds.

\section{Acknowledgements}

Part of the in vitro experiments was conducted within the Center of Genomic Medicine from the 'Victor Babes' University of Medicine and Pharmacy (POSCCE Project ID: 1854, SMIS code: 48749, 'Center of Genomic Medicine v2', contract no. 677/09.04.2015; Timisoara, Romania). The GC-MS and LC-MS analysis of VO and TE were performed in the Interdisciplinary Research Platform (PCI), belonging to Banat's University of Agricultural Sciences and Veterinary Medicine 'King Michael I of Romania' (Timisoara, Romania).

\section{Funding}

The present study was financially supported by an internal grant funded by 'Victor Babes' University of Medicine and Pharmacy (project no. P III-C4-PCFI-2016/2017-04; Timisoara, Romania).

\section{Availability of data and materials}

The datasets used during the present study are available from the corresponding author upon reasonable request.

\section{Authors' contributions}

RAP, IPi, CAD, HTS and DV made a major contribution to the conceptualization, validation, writing, reviewing and editing of the manuscript. IPo and EA obtained, analyzed and interpreted the data regarding volatile oil and extracts. CGF, DC and CD performed in vitro assays (analysis and interpretation). DV and VL contributed to the writing of the manuscript, methodology and project resources. All authors read and approved the final manuscript.

\section{Ethics approval and consent to participate}

Not applicable.

\section{Patient consent for publication}

Not applicable.

\section{Competing interests}

The authors declare that there is no competing of interests.

\section{References}

1. Zavatti M,Zanoli P,Benelli A, Rivasi M,Baraldi C and Baraldi M: Experimental study on Satureja montana as a treatment for premature ejaculation. J Ethnopharmacol 133: 629-633, 2011.

2. Charles DJ: Savory. In: Antioxidant Properties of Spices, Herbs and Other Sources. Springer, New York, NY, pp531-536, 2012.

3. Tepe B and Cilkiz M: A pharmacological and phytochemical overview on Satureja. Pharm Biol 54: 375-412, 2016.

4. Yesiloglu Y, Sit L and Kilic I: In vitro antioxidant activity and total phenolic content of various extracts of Satureja hortensis L. collected from Turkey. Asian J Chem 25: 8311-8316, 2013.

5. Hamidpour R, Hamidpour S, Hamidpour M, Shahlari M and Sohraby M: Summer Savory: From the selection of traditional applications to the novel effect in relief, prevention, and treatment of a number of serious illnesses such as diabetes, cardiovascular disease, Alzheimer's disease, and cancer. J Tradit Complement Med 4: 140-144, 2014.

6. Antal DS, Coricovac D, Soica CM, Ardelean F, Panzaru I, Danciu C, Vlaia V and Toma C: High cadmium content in wild-growing medicinal plants from South-Western Romania unexpected results of a survey on 29 species. Rev Chim 65: 1122-1125, 2014

7. Dehelean CA, Soica C, Pinzaru I, Coricovac D, Danciu C, Pavel I, Borcan F, Spandidos DA, Tsatsakis AM and Baderca F: Sex differences and pathology status correlated to the toxicity of some common carcinogens in experimental skin carcinoma. Food Chem Toxicol 95: 149-158, 2016

8. Lupu M, Caruntu A, Caruntu C, Papagheorghe LML, Ilie MA, Voiculescu V, Boda D, Constantin C, Tanase C, Sifaki M, et al: Neuroendocrine factors: The missing link in non-melanoma skin cancer (Review). Oncol Rep 38: 1327-1340, 2017.

9. Neagu M, Caruntu C, Constantin C, Boda D, Zurac S Spandidos DA and Tsatsakis AM: Chemically induced skin carcinogenesis: Updates in experimental models (Review). Oncol Rep 35: 2516-2528, 2016.

10. European Pharmacopoeia 7.0. https://www.scribd.com/ doc/38363641/European-Pharmacopoeia-7-0-2011. Accessed February 5, 2018.

11. Van den Dool H and Kratz PD: A generalization of the retention index system including linear temperature programmed gas - liquid partition chromatography. J Chromatogr A 11: 463-471, 1963

12. Zălaru C, Crişan CC, Călinescu I, Moldovan Z, Ţârcomnicu I, Litescu SC, Tatia R, Moldovan L, Boda D and Iovu M: Polyphenols in Coreopsis tinctoria Nutt. fruits and the plant extracts antioxidant capacity evaluation. Open Chem 12: 858-867, 2014.

13. Pinzaru I, Heghes A, Marti D, Dehelean C, Coricovac D, Tăculescu (Moacă) EA, Moatar M and Camen D: Therapeutically potential of Medicago sativa extracts chemical and in vitro assessments. Rev Chim 69: 121-124, 2018.

14. Zengin G, Locatelli M, Carradori S, Mocan AM and Aktumsek A: Total phenolics, flavonoids, condensed tannins content of eight centaurea species and their broad inhibitory activities against cholinesterase, tyrosinase, $\alpha$-amylase and $\alpha$-glucosidase. Not Bot Horti Agrobot Cluj-Napoca 44: 195-200, 2016. 
15. Coricovac DE, Moacă EA, Pinzaru I, Cîtu C, Soica C, Mihali CV, Păcurariu C, Tutelyan VA, Tsatsakis A and Dehelean CA: Biocompatible colloidal suspensions based on magnetic iron oxide nanoparticles: Synthesis, characterization and toxicological profile. Front Pharmacol 8: 154, 2017.

16. Cocan I, Alexa E, Danciu C, Radulov I, Galuscan A, Obistioiu D, Morvay AA, Sumalan RM, Poiana MA, Pop G, et al: Phytochemical screening and biological activity of Lamiaceae family plant extracts. Exp Ther Med 15: 1863-1870, 2018.

17. Călina D, Docea AO, Rosu L, Zlatian O, Rosu AF, Anghelina F, Rogoveanu O, Arsene AL, Nicolae AC, Drăgoi CM, et al: Antimicrobial resistance development following surgical site infections. Mol Med Rep 15: 681-688, 2017.

18. National Institute of Standards and Technology: NIST Chemistry WebBook. https://webbook.nist.gov. Accessed August 21, 2017.

19. Sefidkon F, Abbasi K and Khaniki GB: Influence of drying and extraction methods on yield and chemical composition of the essential oil of Satureja hortensis. Food Chem 99: 19-23, 2006.

20. Mohtashami S, Rowshan V, Tabrizi L, Babalar M and Ghani A Summer savory (Satureja hortensis L.) essential oil constituent oscillation at different storage conditions. Ind Crops Prod 111: 226-231, 2018.

21. Katar D, Kacar O, Kara N, Aytac Z, Göksu E, Kara S, Katar N, Erbaş S, Telci I and Elmastaş M: Ecological variation of yield and aroma components of summer savory (Satureja hortensis L.). J Appl Res Med Aromat Plants 7: 131-135, 2017.

22. Alizadeh A, Khoshkhui M, Javidnia K, Firuzi O, Tafazoli E and Khalighi A: Effects of fertilizer on yield, essential oil composition, total phenolic content and antioxidant activity in Satureja hortensis L. (Lamiaceae) cultivated in Iran. J Med Plants Res 4: 33-40, 2010.

23. Tozlu E, Cakir A, Kordali S, Tozlu G, Ozer H and Aytas Akcin T: Chemical compositions and insecticidal effects of essential oils isolated from Achillea gypsicola, Satureja hortensis, Origanum acutidens and Hypericum scabrum against broadbean weevil (Bruchus dentipes). Sci Hortic (Amsterdam) 130: 9-17, 2011.

24. Chkhikvishvili I, Sanikidze T, Gogia N, Mchedlishvili T, Enukidze M, Machavariani M, Vinokur Y and Rodov V: Rosmarinic acid-rich extracts of summer savory (Satureja hortensis L.) protect Jurkat T cells against oxidative stress. Oxid Med Cell Longev 2013: 456253, 2013

25. Mašković P, Veličković V, Mitić M, Đurović S, Zeković Z, Radojković M, Cvetanović A, Švarc-Gajić J and Vujić J: Summer savory extracts prepared by novel extraction methods resulted in enhanced biological activity. Ind Crops Prod 109: 875-881, 2017

26. Coricovac DE and Dehelean CA: Pathological aspects with global impact induced by toxicants at cellular level. In: Toxicology Studies - Cells, Drugs and Environment. Andreazza AC and Scola G (eds). InTech, Rijeka, pp3-21, 2015.

27. Corina D, Florina B, Iulia P, Cristina D, Rita A, Alexandra P, Virgil P, Hancianu M, Daliana M and Codruta S: Rutin and its cyclodextrin inclusion complexes: Physico-chemical evaluation and in vitro activity on B164A5 murine melanoma cell line. Curr Pharm Biotechnol 18: 1067-1077, 2018.

28. Rezvanpanah S, Rezaei K, Golmakani MT and Razavi SH Antibacterial properties and chemical characterization of the essential oils from summer savory extracted by microwave-assisted hydrodistillation. Braz J Microbiol 42: 1453-1462, 2011.
29. Farzaneh M, Kianib H, Sharicfi R, Raeisi M and Hadian J: Chemical composition and antifungal effects of three species of Satureja (S. hortensis, S. spicigera, and S. khuzistanica) essential oils on the main pathogens of strawberry fruit. Postharvest Biol Technol 109: 145-151, 2015.

30. Adiguzel A, Ozer H, Kilic $\mathrm{H}$ and Cetin B: Screening of antimicrobial activity of essential oil and methanol extract of Satureja hortensis on food borne bacteria and fungi. Czech J Food Sci 25: 81-89, 2007.

31. Mahboubi M and Kazempour N: Chemical composition and antimicrobial activity of Satureja hortensis and Trachyspermum copticum essential oil. Iran J Microbiol 3: 194-200, 2011.

32. Mihajilov-Krstev T, Radnović D, Kitić D, Zlatković B, Ristić M and Branković S: Chemical composition and antimicrobial activity of Satureja hortensis L. essential oil. Cent Eur J Biol 4: 411-416, 2009.

33. Sani TA, Mohammadpour E, Mohammadi A, Memariani T, Yazdi VM, Rezaee R, Calina D, Oana DA, Goumenou M, Etemad L, et al: Cytotoxic and apoptogenic properties of Dracocephalum kotschyi aerial part different fractions on calu- 6 and mehr-80 lung cancer cell lines. Farmacia 65: 189-199, 2017.

34. Caruntu C, Boda D, Constantin C, Caruntu A and Neagu M: Catecholamines increase in vitro proliferation of murine B16F10 melanoma cells. Acta Endocrinol (Copenh) 10: 545-558, 2014.

35. Stanojković T, Kolundžija B, Ćirić A, Soković M, Nikolić D and Kundaković T: Cytotoxicity and antimicrobial activity of Satureja kitaibelii wierzb. Ex heuff (Lamiaceae). Dig J Nanomater Biostruct 8: 845-854, 2013.

36. Esmaeilbeig M, Kouhpayeh SA and Amirghofran Z: An investigation of the growth inhibitory capacity of several medicinal plants from Iran on tumor cell lines. Iran J Cancer Prev 8: e4032, 2015.

37. Lampronti I, Saab AM and Gambari R: Antiproliferative activity of essential oils derived from plants belonging to the Magnoliophyta division. Int J Oncol 29: 989-995, 2006.

38. Rajput JD, Bagul SD, Tadavi S and Bendre RS: Comparative anti-proliferative studies of natural phenolic monoterpenoids on human malignant tumour cells. Med Aromat Plants (Los Angel) 5: 279, 2016 .

39. Yang J, Xiao P, Sun J and Guo L: Anticancer effects of kaempferol in A375 human malignant melanoma cells are mediated via induction of apoptosis, cell cycle arrest, inhibition of cell migration and downregulation of $\mathrm{m}-\mathrm{TOR} / \mathrm{PI} 3 \mathrm{~K} / \mathrm{AKT}$ pathway. J BUON 23: 218-223, 2018

40. Heo JR, Lee GA, Kim GS, Hwang KA and Choi KC: Phytochemical-induced reactive oxygen species and endoplasmic reticulum stress-mediated apoptosis and differentiation in malignant melanoma cells. Phytomedicine 39: 100-110, 2018.

41. Cao HH, Tse AK, Kwan HY, Yu H, Cheng CY, Su T, Fong WF and Yu ZL: Quercetin exerts anti-melanoma activities and inhibits STAT3 signaling. Biochem Pharmacol 87: 424-434, 2014.

42. Cao HH, Cheng CY, Su T, Fu XQ, Guo H, Li T, Tse AK, Kwan HY, $\mathrm{Yu} \mathrm{H}$ and $\mathrm{Yu} \mathrm{ZL}$ : Quercetin inhibits $\mathrm{HGF} / \mathrm{c}-\mathrm{Met}$ signaling and HGF-stimulated melanoma cell migration and invasion. Mol Cancer 14: 103, 2015.

This work is licensed under a Creative Commons

Attribution-NonCommercial-NoDerivatives 4.0 International (CC BY-NC-ND 4.0) License. 